Our Nature (2004) 2:27-32

\title{
Medicinal Plants used by Meche People of Jhapa District, Eastern Nepal
}

\author{
S.K. Rai \\ Tribhuvan University \\ Department of Botany \\ Post Graduate Campus, Biratnagar, Nepal \\ E-mail: shivarai2003@yahoo.com
}

\begin{abstract}
The communication deals with ethno-medicinally important plants of Meche community, residing in Jhapa district, Eastern Nepal. 64 species belonging to 29 dicots, 3-monocot families including 1 fern have been found to be used.
\end{abstract}

Keywords: Meche, Ethnomedicine, Jhapa, Bodo

\section{Introduction}

Jhapa district lies in the eastern terai region of Nepal that covers the area approximately $1606 \mathrm{~km}^{2}$. The area falls under tropical climate and vegetation are predominantly of mixed broad-leaved wet monsoons deciduous type. A Mongolian people residing in Mechi river (eastern boarder of country) locality of this district are known as Meche. They are also called Bodo, who mainly inhibit in Jalthal and Dhaijan VDCs (Rai and Dhungana 2002). Their total population is 3673 (Anonymous 2002). Bodo and Dhimal people consider themselves closer to each other both in origin and in their economic lives than any other people (Bista 1967).

Earlier contributions on the medicinal practices and beliefs of different ethnic groups of Nepal have been made by many workers such as: Chepang (Manandhar 1989a, 1989b; Basnet et al. 1998, Khan 1998 Joshi and Ranjit 1999), Danuwar (Manandhar 1990), Daria (Dangol and Gurung 1999), Gurung (Acharya 1996, Shrestha 1998), Limbu (Siwakoti and Siwakoti 1998), Magar (Acharya 1996), Mooshar (Manandhar 1986), Rai (Toba 1975,
Dahal 1999), Raute (Manandhar 1998), Satar (Siwakoti et al. 1997), Sherpa (Bhattarai 1989), Tamang (Toffin and Wiart 1985, Manandhar 1991) and Tharu (Manandhar 1985, Dangol and Gurung 1991, Muller-Boker 1993, Shrestha and Nobuo 1995-96, and Acharya 1996), and record on ethnomedicinal study of Meche tribe of Nepal are vacant, therefore, the present paper aims to highlight the ethnomedicinal informations of Meche.

\section{Materials and Methods}

In formations on medicinal uses of plants and their parts were collected after discussion with their healer (Dausi and Raja). Both participatory Rural Appraisal (PRA) and interview methods were used to record the data. The tribal name, ailments (for which the plant parts used) and other related information was also recorded. The herbarium specimens were identified using relevant literatures (Collet 1921, Siwakoti 1995) and tallied with the herbarium specimens housed at Tribhuvan University, Post Graduate Campus, Biratnagar, Nepal and the voucher specimens have been deposited also there. 


\section{S. K. Rai / Our Nature (2004) 2:27-32}

\section{Enumeration}

The plant species are enumerated below alphabetically by botanical name, family in parenthesis, tribal name followed uses.

Achyranthes aspera (Amaranthaceae), Samulthamarga. Crushed root (ca $10 \mathrm{gm}$ ) are mixed with water (ca $100 \mathrm{~m}$.) and given twice everyday to cure pneumonia.

Acorus calamus (Araceae), Buchhi-roda. Rhizome paste (teaspoonful) is given twice a day for 10 days to get relief from chronic cough. Allium sativum (Liliaceae), Saambram. Bulb with rhizome of Curcuma angustifolia are crushed and mixed with oil of Brassica campestris and applied on wounds as antiseptic.

Aloe vera (Liliaceae), Ghyukumari. Leaf juice is applied on fresh burns. Juice is also given to diabetic patients and in urinal troubles.

Alstonia scholaris (Apocynaceae), Sayotonabimfang. Filtered bark juice (4 to 5 spoonful) are used once daily for one month to cure leanness in man.

Annona squamata (Annonaceae).Bark juice (ca $50 \mathrm{ml}$.) are drunk daily for three consecutive days to control fever.

Artemisia dubia (Asteraceae), Gokhagansu. Leaf extract (5 to $10 \mathrm{ml}$, depending on age) is given for three alternate days to kill round worms.

Artocarpus lakoocha (Moraceae),Dawa. Latex is applied on skin and a thin paper is sticked over it.

Azadirachta indica (Meliaceae), Nimbilai. Leaves are boiled in water and bath is taken with the warm water to cure scabies and eczema. Dried leaf powder is taken as blood purifier.

Blumea lacera (Asteraceae), Gangansu. Root paste is sticked on and around swelling region to prevent from cutaneous infection.
Bombax ceiba (Bombacaceae), Simal. Powder (ca $5 \mathrm{gm}$ ) prepared by pounding the prickle is eaten twice daily to get relief from diarrhoea and dysentery.

Caesalpinia bonduc (Leguminosae), Sugrong-bithai. Seeds are fried to black in coconut oil, crushed and its paste is applied on scalp with the help of cock's feather for baldness.

Callicarpa macrophylla (Verbenaceae). Root decoction (ca $10 \mathrm{ml}$ ) is drunk twice a day for fifteen days to cure bronchitis.

Calotropis gigantea (Asclepiadaceae), Gogando-bimtang. Latex are applied on the joints and followed by sticking of warmed fever repeatedly to get instant relief from rheumatism and sprains.

Carica papaya(Caricaceae). Thul-mul. Latex is applied for ringworm twice daily for ten days.

Cassia fistula (Leguminoseae), Mukhra laudhi. Fruit paste (one teaspoonful) is eaten twice daily for five days to treat the whopping cough.

Cassia occidentalis (Leguminosae). Seed and flower paste is applied in minor skin infection and inflammation.

Catharanthus rosea(Apocynaceae), Gofatbhiwar. Six to ten raw flowers are eaten daily throughout the life to maintain body sugar level for diabetic patients.

Centella asiatica(Apiaceae). Whole plant extract (ca 30 to $50 \mathrm{ml}$ ) is eaten daily for thirty or more days to cure heating and tenderness of limb skin.

Cinnamomum tamala (Lauraceae). Green leaves chewed to cure throat allergy. Leaf powder is eaten with water to increase appetite.

Clerodendrom varecosum (Verbenaceae), Lakhanaat. Root paste is given to reduce 


\section{S. K. Rai / Our Nature (2004) 2:27-32}

the effect of poison taken orally.

Colebrookea oppositifoila (Lamiaceae), Dhusor. Leaf paste is applied in wounds and inflammation of skin.

Crotalaria pallida (Leguminosae). Root paste (one teaspoonful) are drunk with water for three consecutive days to cue body-swelling problem.

Curcuma angustifolia (Zingiberaceae), Nauhaine-haldai. Dried rhizome powder is used as antiseptic in cuts, wounds and to check bleeding.

Cuscuta reflexa (Convolvulaceae), Bimfang-gummu-bindong. Seeds are pasted and eaten orally (ca $5 \mathrm{gm}$ ) as well as applied on the body daily for seven days for jaundice. Datura stramonium (Solanaceae), Gofatdothrabithai. Three seeds are pasted and eaten as single dose to treat scabies.

Drymaria cordata (Caryophyllaceae), Hachiyo-gara-gamso. Leaf pasted with Urena lobata are applied for cutaneous infections.

Elephantopus scaber(Asteraceae), Dadari. Root paste applied on the muscular pain.

Eupatorium odoratum (Asteraceae), Daubanthu. Fresh leaf juice is applied on cut and injury as haemostatic and to check nasal bleeding. Two drops of leaf extract dropped in nose to cure severe headache

Equisetum debile(Equareetaceae), Haal goda. Whole plant are pasted with rhizome of Drymaria cordata and applied on bone factures; the region is supported by bamboo sticks.

Euphorbia hirta(Euphorbiaceae), GofatKhalakhachri. Paste of young shoots (one teaspoonful) is drunk daily for five to seven consecutive days to treat excessive bleeding during menstruation and also in gonorrhea. Latex is applied on pimples and old wounds. Euphorbia royleana(Euphorbiaceae), Sijau.
Latex is applied to cure swelling of skin due to cutaneous and sub-cutaneous infection.

Gossypium hirsutum(Malvaceae), Kawas. Cotton from green capsule are chewed for tongue and gum infection

Hibiscus sabdariffa (Malvaceae), Mahar etha. Leaf of the plant and Lawsonia inermare are pruned and applied on the foot to cure the wound caused by muddy water during rainy season.

Hydrocotyle sibthorpioides (Apiaceae), Manemumi. Plant leaf and Centella asiatica are pasted and extract are given to cure asthma.

Jatropha curcas (Euphorbiaceae), Aanda. Latex is applied to treat toothache and swelling testis.

Justicia vasica (Acanthaceae), Jantrashi. Young leaf extract (ca $25 \mathrm{ml}$ ) are given three to four times daily to cure wheezing in children.

Leucus indica(Lamiaceae), Khaangkareha. Crushed leaves with Euphorbia hirta is let to inhale for sinusitare and nasal infection.

Mangifera indica (Anacardiaceae), Thaijau. Green epidermal peel (very thin) of unripe fruit are crushed and drunk with water to get relief from stomachache.

Mentha arvensis(Lamiaceae), Varegansa. Leaves chewed to clear the obstruction in throat due to cough.

Moringa oleifera(Moringaceae), Sajanamakharia. Flower and capsules are eaten as vegetables to control blood pressure.

Nicotiana tabacum (Solanaceae), Leaf decoction is applied on hair to remove lice.

Ocimum basilicum (Lamiaceae), Leaf juice is applied externally for skin allergy and irritation, twice a day till recovery.

Ocimum gratissimum(Lamiaceae), Ramtulsi. Leaf extract is eaten with sugar to get relief from chest pain and respiratory problem. 
Ocimum tenuiflorum(Lamiaceae), Tulsi. Leaf extract is warmed with honey and eaten (one tea spoon full) twice daily upto seven days to get relief from cough. Leaves are chewed for throat allergy.

Oroxylum indicum (Bignoniaceae), Totalabimfang. Endosperms of two seeds are eaten daily to cure pneumonia. Bark powder are applied on chronic wounds.

Persicaria barbata(Polygonaceae), Bareputuli. Plant leaves and cloves of Allium sativum are pasted together and applied on ringworm after slightly scouring the wound by warm salt-water.

Physalis peruviana (Solanaceae), Gangathopa. Root is pounded with water and drunk (half spoonfull) for four to ten days to cure jaundice in children.

Piper betle(Piperaceae), Faatai-bilai. Leaves including petiole are faintly fried in Ghee and eaten (two leaves) daily for five to seven days to cure dry cough in children.

Piper longum (Piperaceae), Chhimpri-gupai. Root paste (one teaspoonful) is given daily for ten days to treat pneumonia in adults.

Psidium guajava (Myrtaceae), Tham. unripe fruits are eaten control diarrhoea and dysentery.

Rauvolfia serpentina(Apocynaceae), Kharokha. Young shoot extract (ca $10 \mathrm{ml}$ ) are given three times daily to cure pneumonia in early stage.

Ricinus communis(Euphorbiaceae), Aadi. Seed endosperm is applied as cream on dryness of skin and to cure cracking of heels. Scoparia dulcis(Scrophulariaceae), Chineebimfang. Leaf extract are drunk and also applied externally on the body as the remedy for the babies weeping all days.
Semecarpus anacardium (Anacardiaceae), Bhalau. Scars are made by hot fruit on the sides of forehead to cure long and severe headache.

Sesamum orientale(Pedaliaceae), Siwing. Seeds are chewed and applied on skin for sunburns and ringworm every morning and evening untill recovery.

Solanum aculeatissimum (Solanaceae), Goglang. Six seeds are boiled in a cup of water and vapour is taken opening the mouth just above the boiling water to kill the germs of teeth.

Syzygium cumini(Myrtaceae), Jamun. Bark juice $(20 \mathrm{ml})$ are drunk twice a day for five days in dysentery.

Tagetes erecta(Asteraceae), Demal-bhiwar. Leaf juice (half cup) is drunk twice a day for five days to cure pneumania and also in chest pain.

Tamarindus indica(Leguminosae), Titri. Paste of three seeds is eaten to cure stomachache.

Terminalia bellirica(Combretaceae), Bhaayure. Four fruits are powdered and it is drunk with cold water to get relief from constipation.

Terminalia chebula(Combretaceae), Silikhaa. Two fruits are powdered and it is drunk with warm water everyday in gastric ful till recovery.

Urena lobata(Malvaceae), Sam-thai. Young leaves with aerial part of Drymaria cordata are pasted and applied for skin infection and eczema.

Ziziphus oenoplia(Rhamnaceae), Airee. Three seeds are pasted and eaten daily to cure urological problem specially in blocking of urine during urination. 


\section{S. K. Rai / Our Nature (2004) 2:27-32}

\section{Results and Discussion}

The present investigation enumerates 64 medicinal plants practiced and believed by Meche tribe for different ailments. Among them, 22 species are also included in 'National Register of Medicinal Plants' by IUCN Nepal.

The work has brought to light some hidden but popular prescriptions of an ethnic group. A concrete list of plants and their utilization will provide basic data for further studies aimed at conservation, cultivation, healthcare and economic welfare of rural and tribal people.

\section{Acknowledgements}

The author is thankful to National Botanical Research institute (NBRI), Lucknow, India for library facility.

\section{References}

Anonymous 2002. Nepal Population Report. HMJ, Ministry of Population and Environment, Kathmandu, Nepal.

Acharya, S.K. 1996. Folk uses of some medicinal plants of Pawanagar, Dang District. J. Nat. Haret. Mus. (Nepal). 15(1-4): 25-36.

Basnet, B.K., R. Joshi and H.D. Lekhak 1998. Ethnohotanical survey of Chepang tribe of Makwanpur District, Central Nepal. Abstract. In: International Conference on Environment and Agriculture (Nov. 1.3 1998, Kathmandu, Nepal).

Bhatarai, N.K. 1989. Traditional phytotherapy among the Sherpas of helambu, Central Nepal. J. Ethnopharmacol. 27(1/2): 45-54.

Bista, D.R. 1967. People of Nepal. Ratna Pustak Bhandar, Kathmandu, Nepal.p143.

Collet, H. 1921. Flora Simlensare. Thacker, Spink \& Company.

Dahal, M. 1999. Ethnobotany of Aathpabaria Rai in and around Dhankuta Bazaar-Poster. Abstract E-5. In: Bio-refor, Biotechnology applications for reforestation and biodiversity conservation, $8^{\text {th }}$ International Workshop of BIO-REFOR, NOV. DEC.2, 1999, Kathmandu, Nepal. p:75.

Dangol, D.R. and S.B. Gurung 1991. Ethno-botany of the Tharu tribe of Chitwan District, Nepal. Int, J.pharmacognosy 29(3):203-209.

Dangol, D.R. and S.B. Gurung 1999. Ethnobotanical study of Darai tribe in Chitwan, Nepal. Abstract, BSC-2038. In: III National conference on Science and Technology: Abstracts, March 8-11, 1999, Royal Nepal Academy of Science and Technology, Kathmandu, Nepal, pp: 8687.

IUCN 2000. National Registered of Medicinal Plants. Hare Majesty's Government, Minaretry of forest and soil conservation, Nepal.

Joshi, R.,K. Bansyat and R. Ranjit 1999. Study on some wild edible plants of chapangs. Abstract, BSC-087. In: III National Conference on Science and Technology: Abstracts, March 811, 1999. Royal Nepal Academy of Science and Technology, Kathmandu, Nepal. p: 115.

Khan, M. H.1998. Documentation of indigen -ous knowledge in the Chepang community of Shakti Khor VDC, Chitawan. In:Shrestha, K.K. et al. (Eds.), Ethnobotany for conservation and community development. Proceedings of the national Training Workshop in Nepal, January 6-13, 1997, Ethnobotanical Society of Nepal, Kathmandu, Nepal. pp:96-101.

Kunwar, R.R. 1989. Fire of Himal. Nirala Publications, New Delhi, India.

Manandhar, N.P. 1985. Ethnobotanical notes on certain medicinal plants used by Tharu of Dang-Deukhauri District, Nepal. Int. J. Crude Drug Res. 23(4): 153-159

Manandhar, N.P. 1986. A contribution to the ethnobotany of Mooshar tribe of Dhanusha District, Nepal. J. Nat. Hist. Museum (Nepal). 10(1-4):53-64. 
S. K. Rai / Our Nature (2004) 2:27-32

Manandhar, N.P. 1989a. Medicinal plants used by Chepang tribe of Makawanpur District, Nepal. Fitoterapia (Italy) 60(1): 61-68.

Manandhar, N.P. 1989b. Ethnobotanical claims of Chepang of Makawanpur District in Central Nepal. Abstract. In: Proceedings of National Conference on Science and Technology, April 24-29, 1988, Royal Nepal Academy of Science and Technology, Kathmandu, Nepal. p: 397.

Manandahar, N.P. 1990. Traditional phytotherapy of Danuwar tribe of Kamalkhong in Sindhuli District, Nepal. Fitoterapia (Italy). 61(4): 325332.

Manandhar, N.P. 1991. Medicinal plant lore of Tamang tribe of Kabhrepalanchowk District, Nepal. Eco. Bot. 45(1): 58-71.

Manandhar, N.P. 1998. Native phytotherapy among the Raute tribeof Dadeldhura district, Nepal. $J$. Ethnopharmacology 60(3): 199-206. Muller Boker, U. 1993. Ethnobotanical studies among Chitwan's Tharu. J. Nepal ResearchCentre 9: 17-56.

Rai, S.K. and P. Dhungana 2002. Value of plants in cultural and ritual ceremonies of Meche tribe. Vishleshan. Nepal University Teachers Association, Post Graduate Campus, Biratnagar, Nepal. 5 (1): 72-75.

Sacherer, J. 1979. The high altitude ethnobotany of the Rolwaling Sherpa. Contribution to
Nepalese Studies (Nepal). 4(2):45-64.

Shrestha, I. 1998. Ethnomedicobotanical studies of Gurung communities in Bichaur Village, Lamjung, Nepal. Report. International Centre for Integrated Mountain Development, Kathmandu, Nepal. p: 70.

Shrestha, K. and K. Nobuo 1995-96. Ethnobotanical Knowledge of Pongamia pinnata (L.) Pierre in the Ranatharu tribe in Kanchanpur District of Far Western Nepal. Ibid. 5-6(1-4). pp: 28-31.

Siwakoti, M. 1995. Flora of Plain Region of Eastern Nepal. Ph.D. Thesis, T. M. Bhagalpur University, India.

Siwakoti, M., S. Siwakoti and S.R. Varma 1997. Ethnobotanical notes on wild edible plants used by Satars of Nepal. T.U. Journal. 20(1): 57-64.

Siwakoti, M. and S. Siwakoti 1998. Ethnomedicinal uses of plants among the Limbu, Morang District, Nepal. Ecoprint . 5(1): 79-84.

Toba, S. 1975. Plant names in Khaling, a study in ethnobotany and village economy. Kailash (Nepal) 3(2): 145-169.

Toffin, G. and J. Wiart 1985. Recherches sur l'ethnobotanidue des Tamang dumassif du Ganesh Himal (Nepal Central): Les plantes non cultivees. J. D'Agric. Trad. et de Bota. Appl. 32:127-175. 